\title{
MODEL PENINGKATAN KUALITAS PELAYANAN PADA PERGURUAN TINGGI DI RIAU
}

\author{
Layla Hafni \\ layla.hafni@lecturer.pelitaindonesia.ac.id \\ Stefani Chandra \\ Teddy Chandra \\ Pelita Indonesia School of Business
}

\begin{abstract}
Higher education is one of the businesses that offers services to consumers (students). Educational services are inseparable from the competition between campuses in reaching students. For this reason, higher education need to always measure the quality of services provided to students. The purpose of this research was to examine the relationship between service quality, student satisfaction, student loyalty and word-of-mouth on the higher education in Riau province. Samples used are students in 13 (thirteen) university/college in Riau. Exogenous variable used is service quality while endogenous variables are student satisfaction, student loyalty and word-ofmouth. Analysis are done by Structured Equation Modeling (SEM), and Analysis of Variance (ANOVA) assisted by SPSS 21 and AMOS 21. Results of analysis show a significant positive correlation between service quality and student satisfaction, student satisfaction and student loyalty, and student loyalty and word-of-mouth. Service quality with student loyalty and student satisfaction with word-of-mouth has no significant positive correlation.
\end{abstract}

Key words: service quality; student satisfaction; student loyalty, word of mouth; structural equation modeling.

\begin{abstract}
ABSTRAK
Perguruan tinggi merupakan salah satu usaha yang menawarkan jasa kepada konsumen (mahasiswa). Jasa pendidikan tidak terlepas dari persaingan antar kampus dalam meraih mahasiswa. Untuk itu Perguruan tinggi perlu selalu melakukan pengukuran kualitas pelayanan yang diberikan kepada mahasiswa. Tujuan penelitian ini adalah untuk menguji hubungan kualitas pelayanan, kepuasan mahasiswa, loyalitas mahasiswa dan word of mouth pada perguruan tinggi di propinsi Riau. Sampel yang digunakan adalah mahasiswa pada tiga belas university atau college yang ada di Riau, sebanyak 1000 responden. Sebagai exogenous variable adalah kualitas pelayanan sedangkan endogenous variable adalah kepuasan mahasiswa, loyalitas mahasiswa dan word of mouth. Alat analisis yang digunakan dalam penelitian ini adalah structural equation modeling (SEM) dan analysis of variance (ANOVA) dan dibantu dengan menggunakan SPSS 21 dan AMOS 21. Hasil yang diperoleh menunjukkan adanya hubungan positif signifikan antara kualitas pelayanan dengan kepuasan mahasiswa, kepuasan mahasiswa dengan loyalitas mahasiswa dan loyalitas mahasiswa dengan word of mouth. Sedangkan hubungan antara kualitas pelayanan dengan loyalitas mahasiswa dan kepuasan mahasiswa dengan word of mouth tidak mempunyai hubungan positif yang signifikan.
\end{abstract}

Kata kunci: kualitas pelayanan; kepuasan mahasiswa; loyalitas mahasiswa, word of mouth; structural equation modeling.

\section{PENDAHULUAN}

Kualitas produk yang dibuat pada manufaktur sangat mudah diuji dan diidentifikasi. Perusahaan cenderung menggunakan quality control dalam mengawasi kualitas produk yang dihasilkan. Namun kualitas jasa yang dihasilkan oleh perusahaan jasa, sangat sulit diukur. Dengan semakin banyaknya jasa yang ditawarkan kepada konsumen, menjadikan jasa yang dihasilkan juga harus bisa diukur dan dikontrol (Seth et al., 2005). Dengan semakin 
meningkatnya persaingan dan kompleksnya lingkungan bisnis jasa, membuat setiap perusahaan harus selalu melakukan perbaikan kualitas pelayanan secara terus menerus (Bolton et al., 2004).

Penelitian tentang service quality baru berkembang beberapa dekade belakangan ini. Perkembangan tentang service quality sedikit terlambat dibandingkan dengan perkembangan penelitian product quality. Pengukuran product quality sudah sangat jauh, misalnya pada awal tahun 1980 sangat gencar penggunaan Total Quality Management (TQM) dan sejenisnya. Sementara perkembangan penelitian service quality baru mulai menyesuaikan dengan bidang servisnya. Dalam menghadapi persaingan yang semakin ketat, perguruan tinggi perlu melakukan peningkatan service quality, guna meningkatkan student satisfaction dan menghasilkan benefit jangka panjang dalam bentuk market share dan profitability yang lebih besar.

Perguruan tinggi merupakan salah satu usaha jasa yang ditawarkan kepada konsumen (mahasiswa). Jasa pendidikan tidak terlepas dari persaingan antar kampus dalam meraih mahasiswa. Untuk itu Perguruan tinggi juga perlu selalu melakukan pengukuran kualitas pelayanan yang diberikan kepada mahasiswa. Awalnya (Parasuraman et al., 1988) menawarkan pengukuran kualitas pelayanan dengan menggunakan lima dimensi yaitu tangibles, reliability, responsiveness, assurance dan empathy. Namun pengukuran ini dinilai terlalu umum. Beberapa peneliti mengidentifikasikan faktorfaktor penting yang perlu diukur dalam kualitas pelayanan pada Perguruan tinggi adalah (Abdullah, 2006; Alves dan Raposo, 2007; Duarte et al., 2012).

Pada kondisi yang sangat kompetitif saat ini, Perguruan tinggi harus bisa bersaing dengan perguruan tinggi lain termasuk dari luar negeri untuk mendapatkan market share dengan jalan melakukan diferensiasi. Salah satu strategi yang bisa digunakan adalah memberikan kualitas pelayanan yang tinggi (Stevens et al., 1995). Kualitas pelayanan yang tinggi bisa meningkatkan kepuasan konsumen dan menghasilkan benefit jangka panjang dalam bentuk market share dan profitability (Anderson et al., 1994). Penelitian kualitas pelayanan pada perguruan tinggi merupakan hal yang baru dibandingkan dengan penelitian pada sektor komersil, tetapi perguruan tinggi saat ini sudah merupakan prioritas utama dalam kebijakan banyak negara (Sultan dan Yin Wong, 2010). Pada perguruan tinggi, kualitas pelayanan yang tinggi akan menentukan jumlah mahasiswa yang mendaftar (Chen, 2016). Mahasiswa cenderung akan memilih perguruan tinggi yang memberikan kualitas pelayanan dan kepuasan yang tinggi (Tahir et al., 2010). Kepuasan mahasiswa akan memengaruhi loyalitas mahasiswa baik secara langsung maupun melalui kepuasan mahasiswa (Annamdevula dan Bellamkonda, 2016). Jika mahasiswa bisa mendapatkan kepuasan yang tinggi, akan membuat mereka menjadi loyal. Loyalitas mahasiswa akan mendorong mahasiswa untuk disampaikan kepada pihak lain dalam bentuk word of mouth (Alves dan Raposo, 2009; Mansori et al., 2014).

Pada tahun 2018, pemerintah Indonesia mengumumkan rencana untuk membuka pintu bagi perguruan tinggi asing masuk ke Indonesia. Sudah banyak perguruan tinggi asing yang berminat masuk ke Indonesia. $\mathrm{Hal}$ ini membuat perguruan tinggi di Indonesia menjadi ketakutan. Kondisi ini sudah lama dirasakan oleh perguruan tinggi di propinsi Riau. Propinsi Riau sebagai salah satu propinsi yang berdekatan dengan negara tetangga baik Singapura maupun Malaysia. Calon mahasiswa yang akan kuliah di Perguruan tinggi di Riau akan membandingkan perguruan tinggi di Riau dengan perguruan tinggi di Singapore dan Malaysia. Untuk bisa bersaing dengan perguruan tinggi luar negeri, maka perguruan tinggi lokal yang ada di Riau yang berjumlah 109 perguruan tinggi perlu melakukan evaluasi kualitas pelayanan yang diberikan selama ini kepada mahasiswa. Pemerintah saat ini sudah mempunyai komitmen untuk meningkatkan quality dari Perguruan tinggi 
yang ada di Indonesia termasuk di propinsi Riau. Selama ini belum ada penelitian tentang kualitas pelayanan, kepuasan mahasiswa, loyalitas mahasiswa dan word of mouth pada perguruan tinggi di propinsi Riau. Untuk itu perlu ditetapkan tujuan penelitian ini akan menguji hubungan kualitas pelayanan, kepuasan mahasiswa, loyalitas mahasiswa dan word of mouth.

\section{TINJAUAN TEORETIS}

Berikut perlu dilakukan telaah dan diskusi tentang konsep utama dari semua variabel yang diteliti dan hubungannya.

\section{Kualitas pelayanan}

Penelitian tentang kualitas pelayanan awalnya dipopulerkan oleh penelitian yang dilakukan (Parasuraman et al., 1988). Penelitian ini meneliti berbagai bentuk jasa seperti appliance repair and maintenance, retail banking, securities brokerage, long-distance telephone dan credit cards. Hasil penelitian ini memberikan lima dimensi dalam mengukur kualitas pelayanan (SERQUAL) yaitu:

1. Tangibility: fasilitas fisik, peralatan dan penampilan pegawai.

2. Reliability: kemampuan untuk melakukan layanan yang dijanjikan secara andal dan akurat.

3. Responsiveness: kesediaan untuk membantu pelanggan dan kemampuan mereka untuk menginspirasi kepercayaan dan kepercayaan diri.

4. Empathy: perhatian, perhatian individual memberikan kepada pelanggan.

5. Assurance: pengetahuan dan kesopanan karyawan dan kemampuan mereka untuk menginspirasi kepercayaan dan kepercayaan diri.

Hasil ini banyak digunakan oleh penelitian-penelitian yang terkait dengan pengukuran kualitas pelayanan. Namun pengukuran ini juga banyak mendapat kriti kan, sehingga belum bisa ditemukan cara yang terbaik untuk mengukur kualitas pelayanan (Chen, 2016). Pengukuran kualitas di perguruan tinggi juga belum ada konsensus dan belum bisa menemukan kualitas pelayanan yang terbaik. Setiap stakeholder perguruan tinggi adalah unik sehingga tidak bisa disamakan pengukurannya (Gruber et al., 2010). Beberapa peneliti masih menggunakan SERQUAL dengan beberapa modifikasi untuk perguruan tinggi (Afridi et al., 2016; Arambewela dan Hall, 2006; CalvoPorral et al., 2013; Kanakana, 2014; Yousapronpaiboon, 2014). Disamping itu (Abdullah, 2006) menawarkan HEdPERF (Higher Education PERFormance-only) yang memberikan dimensi aspek non-akademik, aspek akademik, reputasi dan program. Sementara penelitian yang dilakukan oleh (Chen, 2016) menemukan faktor-faktor yang menentukan kualitas pelayanan pada perguruan tinggi di Taiwan adalah kampus, staf dan pengajar. Di India, (Senthilkumar dan Arulraj, 2011) menawarkan model penelitian kualitas pelayanan pada perguruan tinggi dengan nama SQM-HEI (Service Quality Measurement in Higher Education in India). Model ini lebih menitikberatkan pada 3 faktor yaitu teaching and methodology (TM), environmental change in study factor (ECSF), disciplinary action (DA) dan placement as the mediating factor and the outcome as the quality education. Begitu juga (Annamdevula dan Bellamkonda, 2016b) menawarkan instrumen kualitas pelayanan yang dikenal dengan HiEduQual (Higher Education Quality).

Bagaimanapun pengukuran kualitas pelayanan di bidang perguruan tinggi masih belum ada kesepakatan. Pada penelitian ini pengukuran kualitas pelayanan akan menggabungkan beberapa model dan menyesuai kan dengan karakteristik stakeholder perguruan tinggi di Indonesia khususnya propinsi Riau.

\section{Pengembangan Hipotesis \\ Pengaruh Kualitas Pelayanan Terhadap Kepuasan mahasiswa}

Pengertian kepuasan berbeda antar peneliti. Tse dan Wilton (1998) menyatakan satisfaction merupakan perceive performance atau kinerja yang bisa dirasakan oleh konsumen. Sementara ada juga yang menyatakan kepuasan konsumen merupakan ke- 
adilan (fairness) (Oliver, 1989). Parasuraman et al., (1985) menawarkan konsep hubungan kualitas pelayanan dengan kepuasan konsumen berdasarkan transaksi. Secara umum konsumen akan merasa puas atau tidak puas, tergantung pada evaluasi harga yang dibayarkan dengan kualitas dari produk atau jasa yang diterima. Konsumen yang tidak pernah komplain bukan berarti pasti merasa puas (Kitapci dan Taylan, 2009). Perlu menjadi perhatian pada pengurus untuk selalu mengukur kepuasan konsumen. Konsep kepuasan pada bidang pendidikan yang sering disebut kepuasan mahasiswa. Penelitian yang masih terbatas mengenai kepuasan mahasiswa disebabkan karena kepuasan mahasiswa merupakan hal yang kompleks (Marzo Navarro et al.,2005).

Hubungan antara kualitas pelayanan dengan kepuasan mahasiswa masih membingungkan dalam teori marketing (Anderson et al., 1994). Parasuraman et al. (1988) menyatakan perceive kualitas pelayanan merupakan antecedent dari kepuasan konsumen. Penelitian yang dilakukan oleh Annamdevula dan Bellamkonda, (2016b, 2016a) menemukan adanya hubungan positif antara kualitas pelayanan dengan kepuasan mahasiswa. Penelitian yang dilakukan oleh Alves dan Raposo, (2009) menemukan adanya hubungan positif signifikan antara kualitas pelayanan dengan kepuasan mahasiswa. Begitu juga penelitian lainnya Duarte et al., (2012) juga menemukan hubungan positif signifikan antara kualitas pelayanan dengan kepuasan mahasiswa, baik current mahasiswa maupun former mahasiswa. Penelitian yang dilakukan oleh Mansori et al., (2014) pada Malaysia private education, menemukan adanya hubungan yang sangat kuat antara tangibility dari salah satu dimensi kualitas pelayanan dengan kepuasan mahasiswa. Pada penelitian ini ditemukan adanya peran yang sangat penting dari fasilitas fisik dari kampus dengan kepuasan mahasiswa. Begitu juga penelitian yang dilakukan pada private tertiary education sector in Singapore, menemukan adanya hubungan positif kualitas pelayanan dengan kepuasan mahasiswa (Khoo et al., 2015). Sebaliknya penelitian yang dilakukan oleh Dib dan Mokhles, (2013) pada perguruan tinggi di Syria tidak menemukan adanya hubungan yang signifikan antara kualitas pelayanan dengan kepuasan mahasiswa.

Dengan melihat hasil kajian penelitian yang ada maka untuk penelitian ini bisa dibuat hipotesis seperti dibawah ini:

$\mathrm{H}_{1}$ : Kualitas pelayanan berpengaruh positif terhadap kepuasan mahasiswa.

\section{Pengaruh Kualitas Pelayanan Terhadap Loyalitas Mahasiswa}

Kendati Cronin dan Taylor, (1992) menyatakan kepuasan konsumen lebih berpengaruh terhadap loyalitas konsumen dibanding dengan kualitas pelayanan, namun sebenarnya baik kepuasan konsumen maupun kualitas pelayanan sama-sama mempunyai pengaruh terhadap loyalitas konsumen. Penelitian yang dilakukan Heung et al. (1996) untuk meneliti tingkat brand loyalty dari hotel di HongKong, menemukan kualitas dari jasa hotel sangat memengaruhi brand loyalty hotel. penelitian ini juga didukung oleh penelitian yang dilakukan (Ngo dan Nguyen, 2016) yang meneliti Vietnamese retail banking sector, menemukan adanya pengaruh positif kualitas pelayanan terhadap loyalitas konsumen.

Penelitian tentang loyalitas mahasiswa pada perguruan tinggi, akan sangat membantu pihak pengurus untuk menetapkan secara tepat program promosi, pengembangan dan mempertahankan keberhasilan hubungan jangka panjang baik dengan mahasiswa maupun alumni (Annamdevula dan Bellamkonda, 2016a). Persepsi kualitas yang positif akan memengaruhi prilaku mahasiswa (Zeithaml et al., 1996). Kualitas mengajar dan emosi mahasiswa akan komitmen pada institusi akan meningkatkan loyalitas mahasiswa (Henning-Thurau et al., 2001). Adanya hubungan positif kualitas pelayanan terhadap loyalitas mahasiswa juga ditemukan oleh Annamdevula dan Bellamkonda, (2016a, 2016b). Sebaliknya 
penelitian yang dilakukan oleh Dib dan Mokhles, (2013) yang meneliti perguruan tinggi di Syria menemukan tidak adanya hubungan yang signifikan antara kualitas pelayanan dengan loyalitas mahasiswa. Dari hasil kajian penelitian sebelumnya maka disini bisa dibuat hipotesis sebagai berikut:

$\mathrm{H}_{2}$ : Kualitas pelayanan berpengaruh positif terhadap loyalitas mahasiswa.

\section{Pengaruh Kepuasan Mahasiswa Terhadap Loyalitas Mahasiswa.}

Loyalitas konsumen merupakan perilaku konsumen untuk mempertahankan hubungan dengan institusi untuk membeli kembali produk dan jasa (Duffy, 2003). Zeithaml et al., (1996) menjelaskan loyalitas bisa ditunjukkan dengan beberapa jalan seperti merekomendasikan perusahaan kepada pihak lain, akan membeli kembali dan meningkatkan business dimasa yang akan datang. Dib dan Mokhles, (2013) menemukan adanya hubungan yang signifikan antara kepuasan mahasiswa dengan loyalitas mahasiswa. Penelitian ini juga didukung oleh penelitian yang dilakukan oleh Annamdevula dan Bellamkonda, (2016a, 2016b) yang menunjukkan adanya hubungan yang sangat kuat antara kepuasan mahasiswa dengan loyalitas mahasiswa. Penelitian yang dilakukan oleh Duarte et al., (2012) juga menemukan adanya hubungan yang sangat kuat antara kepuasan mahasiswa dengan loyalitas mahasiswa. Dari hasil ini bisa dikembangkan hipotesis sebagai berikut:

$\mathrm{H}_{3}$ : Kepuasan mahasiswa berpengaruh positif terhadap loyalitas mahasiswa.

\section{Pengaruh Kepuasan mahasiswa, Loyalitas mahasiswa dan Word of Mouth.}

Berdasarkan penelitian yang dilakukan oleh Olorunniwo et al. (2006) konsumen yang loyal akan memberikan pengaruh pada profitability dan keberhasilan organisasi dengan dua jalan. Pertama, mahasiswa akan melanjutkan studinya pada level yang lebih tinggi pada institusi yang sama. Hal ini akan mengurangi mahasiswa yang keluar dan meningkatkan profit dengan mengurangi cost of marketing dan operating cost. Kedua, Mahasiswa yang puas dan loyal cenderung akan memberikan komentar yang baik dan merekomendasikan institusi kepada orang lain. Hal ini sangat penting bagi industri pendidikan saat ini. Selain membutuhkan biaya rekrutmen mahasiswa yang besar. Hal ini juga disebabkan karena sangat sulit menggunakan pendekatan marketing konvensional (advertising and promotional activities) karena market place dari industri pendidikan akan menjadi global (Vaz dan Mansori, 2013).

Penelitian yang dilakukan oleh Mansori et al., (2014) menemukan adanya hubungan positif dan signifikan antara kepuasan mahasiswa dengan word of mouth. Sebaliknya penelitian yang dilakukan oleh Alves dan Raposo, (2007) yang meneliti pada Portuguese state university, menemukan tidak adanya hubungan yang signifikan antara kepuasan mahasiswa dengan word of mouth. Tetapi pada penelitian yang sama justru menunjukkan adanya hubungan positif yang kuat antara loyalitas mahasiswa dengan word of mouth. Artinya penelitian ini menemukan, mahasiswa yang satisfaction saja tidak akan menyebarkan informasi keluar (word of mouth). Hanya mahasiswa yang puas dan memiliki loyalitas yang tinggi yang akan menyebarkan informasi kepada keluarga dan teman-temannya (word of mouth). Sebaliknya, penelitian yang dilakukan oleh Ranaweera dan Prabhu, (2003) menemukan pentingnya customer yang puas untuk bisa memberikan rekomendasi kepada pihak lain (word of mouth). Dari hasil kajian penelitian sebelumnya bisa dibangun hipotesis sebagai berikut:

$\mathrm{H}_{4}$ : Kepuasan mahasiswa berpengaruh positif terhadap word of mouth.

$\mathrm{H}_{5}$ : Loyalitas mahasiswa berpengaruh positif terhadap word of mouth.

\section{METODE PENELITIAN}

\section{Model Penelitian}

Model penelitian yang dibentuk dan akan diuji sesuai dengan hipotesis yang 
dijelaskan sebelumnya bisa dilihat pada Gambar 1.

Model penelitian menggabungkan variabel kualitas pelayanan yang akan me- mengaruhi kepuasan mahasiswa, loyalitas mahasiswa dan word of mouth. Gambar ini menunjukkan adanya pengaruh langsung dan tidak langsung.

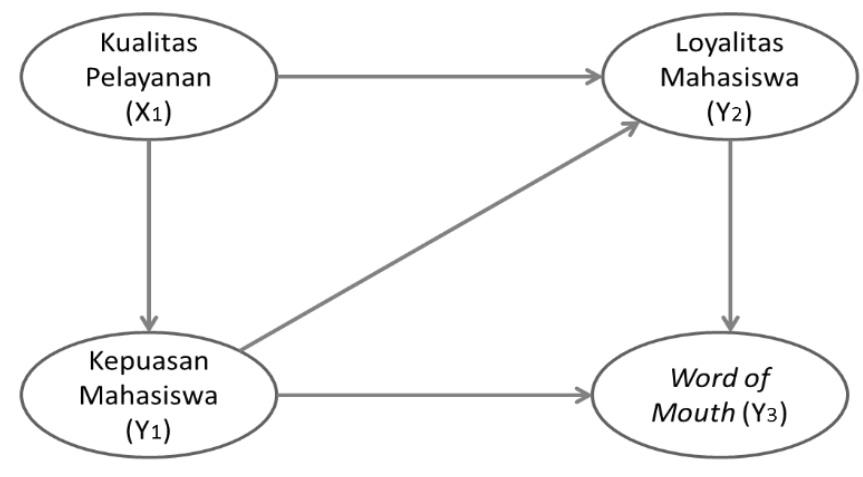

\section{Gambar 1 \\ Model Penelitian}

\section{Instrumen Survei}

Untuk penelitian ini, skala pengukuran dan indikator diadopsi dari penelitian sebelum nya. skala pengukuran dan indikator yang digunakan dalam penelitian ini sebagian sudah pernah digunakan oleh penelitian lain (Abdullah, 2006; Annamdevula dan Bellamkonda, 2016a; de Jager dan Gbadamosi, 2010; Lagrosen et al., 2004; Mahapatra dan Khan, 2007). Indikator yang banyak mengadopsi dari penelitian lain banyak ditemui pada variabel kualitas pelayanan, kepuasan mahasiswa dan loyalitas mahasiswa. Sedangkan untuk indikator word of mouth, dirancang sendiri. Indikator kualitas pelayanan terdiri dua belas indikator, dimana ada sebelas indikator berasal dari (Abdullah, 2006; Annamdevula dan Bellamkonda, 2016a; de Jager dan Gbadamosi, 2010; Lagrosen et al., 2004; Mahapatra dan Khan, 2007), hanya ada satu indikator saja yang dirancang sendiri. Sementara indikator dari variabel kepuasan mahasiswa terdapat tiga indikator berasal dari (Annamdevula dan Bellamkonda, 2016a), hanya ada dua indikator saja yang dirancang sendiri. Begitu juga indikator dari variabel loyalitas mahasiswa yang terdiri atas lima indikator, terdapat dua indikator yang berasal dari (Annamdevula dan Bellamkonda, 2016a), dan ada tiga indikator yang dirancang sendiri. Semua indikator dari variabel kualitas pelayanan, kepuasan mahasiswa, loyalitas mahasiswa dan word of mouth menggunakan skala likert tujuh poin yang terdiri $1=$ sangat tidak setuju sampai $7=$ sangat setuju.

\section{Populasi dan Sampel}

Populasi yang digunakan dalam penelitian ini adalah seluruh mahasiswa yang ada pada perguruan tinggi yang berada di propinsi Riau. Jumlah mahasiswa yang terdaftar adalah sebanyak 95.199 orang. Untuk mendapatkan jumlah sampel yang lebih dari 75000 maka sampel yang harus ada minimal 384 orang (Sekaran, 2003). Jumlah kuesioner yang disebarkan adalah sebanyak 1100, yang kembali sebanyak 1002. Dari 1002 kuesioner, ternyata ada 2 yang harus dieliminasi karena tidak diisi lengkap. Jumlah sampel yang akhirnya bisa digunakan adalah 1000 responden. Jadi kuesioner yang direspon dan valid sebesar $90,91 \%$ $(n=1000)$. Memang tidak memungkinkan untuk mendapatkan semua institution, untuk itu dipilih 13 perguruan tinggi yang bisa mewakili semua populasi. Sampel 
tersebut terdiri atas tiga perguruan tinggi negeri, sepuluh perguruan tinggi swasta (dua universitas, tujuh sekolah tinggi dan satu akademi). Adapun penyebaran sampel berdasarkan perguruan tinggi bisa dilihat dari Tabel 1.

Tabel 1

Jumlah Sampel Berdasarkan Institusi

\begin{tabular}{clcr}
\hline No & \multicolumn{1}{c}{ Institusi } & $\begin{array}{c}\text { Jumlah } \\
\text { Mahasiswa }\end{array}$ & \% \\
\hline 1 & Universitas Riau & 298 & 29.80 \\
2 & Universitas Islam Riau & 102 & 10.20 \\
3 & Universitas Islam Negeri Sultan Syarif Kasim II & 105 & 10.50 \\
4 & STIA Lancang Kuning & 83 & 8.30 \\
5 & STIKES Al Insyriyah & 55 & 5.50 \\
6 & STIKES Hang Tuah & 28 & 2.80 \\
7 & STIMIK Hang Tuah & 20 & 2.00 \\
8 & STIE Pelita Indonesia & 109 & 10.90 \\
9 & Universitas Terbuka Pekanbaru & 4 & 0.40 \\
10 & STMIK Dumai & 77 & 7.70 \\
11 & Akademi Akuntansi Riau Dumai & 43 & 4.30 \\
12 & Universitas Muhammadiyah Riau & 59 & 5.90 \\
13 & STIKES Awal Bros $\quad$ Total & 17 & 1.70 \\
\hline & & 1,000 & 100.00 \\
\hline
\end{tabular}

Sumber: data primer, diolah (2019)

Program studi untuk mahasiswa juga tersebar hampir disemua bidang, seperti yang tergambar pada Tabel 2. Dari pe- nyebaran sampel tersebut bisa mewakili semua mahasiswa dari populasi.

Tabel 2

Sampel Berdasarkan Program Studi

\begin{tabular}{|c|c|c|c|}
\hline No & Program Studi & $\begin{array}{c}\text { Jumlah } \\
\text { Mahasiswa }\end{array}$ & 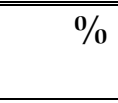 \\
\hline 1 & Bisnis & 540 & 54.00 \\
\hline 2 & Economi & 168 & 16.80 \\
\hline 3 & Keperawatan & 26 & 2.60 \\
\hline 4 & Kesehatan Masyarakat & 14 & 1.40 \\
\hline 5 & Kebidanan & 15 & 1.50 \\
\hline 6 & Rekam Medis & 28 & 2.80 \\
\hline 7 & Ilmu Komputer & 97 & 9.70 \\
\hline 8 & Magister Manajemen & 59 & 5.90 \\
\hline 9 & Teknik Otomotif & 19 & 1.90 \\
\hline 10 & Biologi & 17 & 1.70 \\
\hline 11 & Radiologi & 13 & 1.30 \\
\hline \multirow[t]{2}{*}{12} & Administrasi Rumah Sakit & 4 & 0.40 \\
\hline & Total & 1,000 & 100.00 \\
\hline
\end{tabular}


Jika dilihat demografi lain, juga tersebar seperti gender, usia, tipe perguruan tinggi dan status pekerjaan yang tergambar pada Tabel 3. Pendidikan di Indonesia terdiri atas Diploma 3 (diploma), strata 1 (sarjana),
Strata 2 (Magister) and strata 3 (Doktor). Penelitian ini hanya meneliti mahasiswa diploma, sarjana dan magister. Rata-rata umur mahasiswa baru di perguruan tinggi adalah 18-19 tahun.

Table 3

\section{Profil Responden}

\begin{tabular}{llcc}
\hline \multicolumn{1}{c}{ Demografi } & \multicolumn{1}{c}{ Kategori } & Frekuensi & $\mathbf{( \% )}$ \\
\hline Gender & Pria & 299 & 29.90 \\
Usia & Wanita & 701 & 70.10 \\
& $18-20$ & 533 & 53.30 \\
& $21-24$ & 414 & 41.40 \\
Tipe Perguruan & Perguruan Tinggi Negeri & 16 & 1.60 \\
Tinggi & Perguruan Tinggi Swasta & 37 & 3.70 \\
Pekerjaan & Mahasiswa & 593 & 40.70 \\
& Mahasiswa dan Kerja & 811 & 89.30 \\
& 250 & 189 & 18.90 \\
\hline
\end{tabular}

Sumber: data primer, diolah (2019)

Untuk menyelesaikan program diploma mereka membutuhkan 3 tahun. Untuk menyelesaikan program sarjana membutuhkan 4-5 tahun. Untuk menempuh jenjang magister dibutuhkan lagi 2 tahun. Usia responden diambil 18-20 tahun, yang merupakan mahasiswa yang baru yang telah mengikuti 1 tahun pendidikan. Kemudian 21-24 tahun merupakan mahasiswa yang akan menyelesaikan program diploma dan sarjana. Usia 25-30 merupakan mahasiswa baru lulus yang melanjutkan program magister. Terakhir usia diatas 30 yaitu mahasiswa magister yang sudah punya pengalaman kerja dan mengikuti kuliah lagi.

Perguruan tinggi yang ada di Riau terdiri atas perguruan tinggi negeri dan perguruan tinggi swasta. Selama ini perguruan tinggi negeri merupakan kampus favorit calon mahasiswa. Sedangkan status mahasiswa saat ini pada perguruan tinggi swasta, ada yang hanya menjadi mahasiswa saja, namun ada juga yang bisa sambil bekerja. Alat analisis yang digunakan dalam penelitian ini adalah Structural Equation Modeling (SEM) dan Analysis of Variance (ANOVA), dengan menggunakan IBM SPSS
Statistics version 21 dan IBM AMOS version 21. SEM digunakan untuk menguji causal relationship antara variabel kualitas pelayanan, kepuasan mahasiswa, loyalitas mahasiswa dan word of mouth. Sedangkan Anova digunakan untuk menguji perilaku responden sesuai dengan profil responden.

\section{ANALISIS DAN PEMBAHASAN Uji Validitas and Reliabilitas}

Sebelum digunakan hasil analisis ini, perlu diuji terlebih dahulu uji validitas dan reliabilitas dari instrumen kuesioner. Hasil uji validitas dan reliabilitas bisa dilihat pada Tabel 4. Construct reliability digunakan untuk mengukur konsistensi dan stabilitas dari indikator dalam memberikan kontribusi pada construct. Hasil Construct reliability terlihat pada Tabel 4. Hasil Construct reliability yang diperoleh menunjukkan semua construct nilainya lebih dari 0,900 , padahal batasan yang ditetapkan hanya 0,70 (Hair et al., 1998). Sehingga bisa dikatakan semua construct adalah reliable. Uji Validitas merupakan pengukuran ketepatan dan akurasi alat ukur dalam melakukan fungsi ukur dari instrumen analisis. 
Table 4

Uji Validitas and Reliabilitas

\begin{tabular}{|c|c|c|c|c|c|c|}
\hline Constructs & Indikator & Correlation & $\begin{array}{c}\text { Loading } \\
\text { Factor }\end{array}$ & P value & $\begin{array}{l}\text { Construct } \\
\text { Reliability }\end{array}$ & AVE \\
\hline \multirow{12}{*}{ 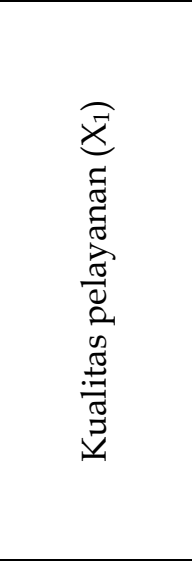 } & $X_{11}$ & 0.606 & 0.605 & $* * *$ & \multirow{12}{*}{0.945} & \multirow{12}{*}{0.589} \\
\hline & $X_{12}$ & 0.779 & 0.783 & $* * *$ & & \\
\hline & $\mathrm{X}_{13}$ & 0.645 & 0.644 & $\star * * *$ & & \\
\hline & $X_{14}$ & 0.697 & 0.701 & $* * *$ & & \\
\hline & $X_{15}$ & 0.794 & 0.792 & $* * *$ & & \\
\hline & $X_{16}$ & 0.805 & 0.811 & $* * *$ & & \\
\hline & $X_{17}$ & 0.774 & 0.814 & $* * *$ & & \\
\hline & $\mathrm{X}_{18}$ & 0.804 & 0.835 & $* * *$ & & \\
\hline & $\mathrm{X}_{19}$ & 0.819 & 0.848 & $* * *$ & & \\
\hline & $X_{110}$ & 0.784 & 0.827 & $* * *$ & & \\
\hline & $X_{111}$ & 0.705 & 0.738 & $* * *$ & & \\
\hline & $X_{112}$ & 0.734 & 0.769 & $* * *$ & & \\
\hline \multirow{6}{*}{ 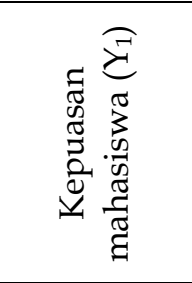 } & $Y_{11}$ & 0.769 & 0.841 & $* * *$ & \multirow{6}{*}{0.912} & \multirow{6}{*}{0.634} \\
\hline & $Y_{12}$ & 0.782 & 0.864 & $* * *$ & & \\
\hline & $Y_{13}$ & 0.814 & 0.862 & $* * *$ & & \\
\hline & $\mathrm{Y}_{14}$ & 0.744 & 0.775 & $* * *$ & & \\
\hline & $\mathrm{Y}_{15}$ & 0.721 & 0.718 & $* * *$ & & \\
\hline & $\mathrm{Y}_{16}$ & 0.702 & 0.700 & $* * *$ & & \\
\hline \multirow{5}{*}{ 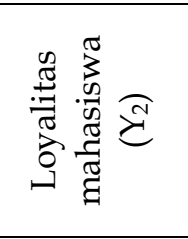 } & $Y_{21}$ & 0.736 & 0.796 & $* * *$ & \multirow{5}{*}{0.924} & \multirow{5}{*}{0.708} \\
\hline & $Y_{22}$ & 0.832 & 0.892 & $* * *$ & & \\
\hline & $\mathrm{Y}_{23}$ & 0.841 & 0.901 & $* * *$ & & \\
\hline & $\mathrm{Y}_{24}$ & 0.777 & 0.817 & $* * *$ & & \\
\hline & $\mathrm{Y}_{25}$ & 0.664 & 0.796 & $* * *$ & & \\
\hline \multirow{5}{*}{ 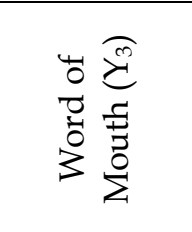 } & $Y_{31}$ & 0.695 & 0.704 & $* * *$ & \multirow{5}{*}{0.913} & \multirow{5}{*}{0.679} \\
\hline & $Y_{32}$ & 0.813 & 0.841 & $* * *$ & & \\
\hline & $Y_{33}$ & 0.831 & 0.896 & $* * *$ & & \\
\hline & $Y_{34}$ & 0.762 & 0.808 & $* * *$ & & \\
\hline & $Y_{35}$ & 0.802 & 0.859 & $* * *$ & & \\
\hline
\end{tabular}

$* * *=p$-value $<0.01$

Sumber: data primer, diolah (2019)

Untuk mengukur validitas dari instrumen analisis bisa dilakukan dengan correlation. Hasil correlation yang diperoleh semua indikator lebih dari 0,600 sehingga bisa dikatakan valid. Jika dilihat dari loading factor yang diperoleh, semua indikator nilainya lebih besar dari 0,600 dengan $p$-value lebih kecil dari 0,000. Artinya semua indikator bisa secara signifikan memberikan kontribusi kedalam construct masingmasing. Dalam analisis confirmatory, juga bisa mengukur convergent validity dari loading factor yang dikenal dengan average variance extracted (AVE) dari construct. Hasil AVE dari analisis ini semuanya diatas 0,500. batasan yang diperbolehkan dalam pengujian AVE ini adalah 0,500 (Hair et al., 1998). Sehingga bisa dikatakan semua indikator dan construct yang ada layak digunakan dalam penelitian ini.

\section{Goodness of Fit}

Untuk bisa menggunakan model analisis SEM, maka perlu dilakukan pengujian terhadap model. Hasil pengujian terhadap model tergambar pada Tabel 5 . 
Tabel 5

Goodness of Fit Result

\begin{tabular}{lccc}
\hline Goodness of Fit Index & Cut-off* $^{*}$ & Hasil & Kesimpulan \\
\hline Chi-Square & & 2144.948 & \\
Probability & $\geq 0.05$ & 0.000 & Marginal \\
G F I & $\geq 0.90$ & 0.857 & Marginal \\
A G F I & $\geq 0.90$ & 0.827 & Marginal \\
T L I & $\geq 0.90$ & 0.914 & Fit \\
C F I & $\geq 0.90$ & 0.923 & Fit \\
N F I & $\geq 0.90$ & 0.911 & Fit \\
I F I & $\geq 0.90$ & 0.923 & Fit \\
RMSEA & $0.05-0.08$ & 0.073 & Fit \\
\hline
\end{tabular}

Sumber: data primer, diolah (2019)

* source: (Hair et al., 1998)

Dari penelitian sebelumnya disarankan untuk menggunakan goodness of fit lebih dari satu kriteria. Pada penelitian ini digunakan delapan kriteria uji goodness of fit. Dari Tabel 5 terlihat bahwa dari delapan kriteria yang diuji, terdapat lima kriteria saja yang fit, yaitu TLI, CFI, NFI, IFI dan RMSEA. Sedangkan untuk chi-square, GFI dan AGFI hanya mendapat marginal. Nilai GFI mencapai 0,857 dan AGFI sebesar 0,827 sudah mendekati critical value $(0,9)$, sehingga belum mencapai batas not applicable atau masih bisa diterima. Nilai chi-square yang besar dan probability sebesar 0,000, ini disebabkan karena jumlah sampel yang sangat besar $(n=$ 200) sehingga tidak bisa diperhitungkan probability-nya (Hair et al., 1998). Sehingga secara keseluruhan pengujian goodness of fit, bisa dikatakan data dari model SEM yang diuji baik dan layak digunakan untuk analisis lebih lanjut.

\section{Analysis of Variance}

Analysis of variance (ANOVA) digunakan untuk menguji perbedaan respon dari responden yang berasal dari demographic profile yang berbeda. Dengan mengetahui perbedaan tersebut, akan membuat lebih jelas prilaku masing-masing demographic profile. Adapun hasil yang diperoleh bisa terlihat pada Tabel 6 .

Secara umum rata-rata tanggapan responden terhadap kualitas pelayanan dianggap biasa saja $(5,258)$. Respon terbaik untuk kualitas pelayanan hanya pada dosen memperlakukan mahasiswa dengan cara yang sama (adil) (5,456). Sedangkan tanggapan terendah menyangkut dengan ruangan kelas bersih dan nyaman $(4,914)$. Sementara tanggapan tentang kepuasan mahasiswa mendapat respon yang lebih baik $(5,585)$. Respon terbaik adalah tentang kepuasan tentang puas dengan kualitas pelayanan akademik $(5,845)$. Sedangkan respon terendah mengenai puas dengan kualitas pelayanan administrasi $(5,317)$. Jika dilihat respon tentang loyalitas mahasiswa, ternyata juga mendapat tanggapan yang cukup baik $(5,676)$. Tanggapan responden terbaik adalah mengenai saya tidak ada rencana untuk pindah ke kampus lain (5.834).

Sedangkan tanggapan terendah mengenai saya akan merekomendasikan kampus ini kepada teman dan keluarga $(5,593)$. Jika dilihat dari sisi word of mouth, ternyata men dapatkan tanggapan yang lebih baik $(5,811)$. Tanggapan terbaiknya adalah tentang saya bangga bisa berbagi pengalaman selama di kampus $(5,915)$. Sedangkan tanggapan terrendah adalah mengenai saya lebih suka berbicara tentang kampus ini dibandingkan dengan kampus lain $(5,665)$.

Dari uji ANOVA untuk profil usia, ternyata banyak terdapat perbedaan. Untuk kualitas pelayanan, rata-rata respon terrendah terjadi pada usia 21-24 tahun $(5,01)$. 
Table 6

Hasil ANOVA Berdasarkan Umur, Gender, Tipe Perguruan Tinggi, Program Studi dan Pekerjaan.

\begin{tabular}{|c|c|c|c|c|c|c|c|c|}
\hline \multirow[b]{2}{*}{ Construct } & \multirow[b]{2}{*}{ Indicators } & \multicolumn{2}{|c|}{ Mean } & \multicolumn{5}{|c|}{ F-test } \\
\hline & & Indikator & Construct & Umur & Gender & Tipe PT & $\begin{array}{l}\text { Program } \\
\text { Studi }\end{array}$ & Pekerjaan \\
\hline \multirow{12}{*}{ 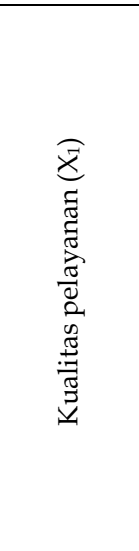 } & $X_{11}$ & 5.456 & \multirow{12}{*}{5.258} & $4.350 * * *$ & 0.095 & 0.551 & $5.250 * * *$ & 1.205 \\
\hline & $\mathrm{X}_{12}$ & 5.196 & & $11.316^{* * *}$ & 1.137 & $13.988^{* * *}$ & $7.536^{* * *}$ & 0.003 \\
\hline & $\mathrm{X}_{13}$ & 5.355 & & $12.236^{* * *}$ & 0.022 & 0.174 & $7.939 * * *$ & 0.004 \\
\hline & $\mathrm{X}_{14}$ & 5.370 & & $8.320^{* * *}$ & $5.487^{* *}$ & 0.388 & $4.812^{* * *}$ & 1.138 \\
\hline & $\mathrm{X}_{15}$ & 5.256 & & $11.345^{* * *}$ & 1.989 & $6.028^{* *}$ & $7.463^{* * *}$ & 1.218 \\
\hline & $\mathrm{X}_{16}$ & 4.950 & & $13.796^{* * *}$ & 1.488 & $21.828^{* * *}$ & $9.043^{* * *}$ & 0.200 \\
\hline & $\mathrm{X}_{17}$ & 4.914 & & $15.571^{* * *}$ & 2.262 & $27.248^{* * *}$ & $8.314^{* * *}$ & 1.480 \\
\hline & $\mathrm{X}_{18}$ & 5.338 & & $10.267^{* * *}$ & $7.134^{* * *}$ & $50.350^{* * *}$ & $11.640^{* * *}$ & $3.665^{*}$ \\
\hline & $\mathrm{X}_{19}$ & 5.267 & & $8.934^{* * *}$ & $9.297^{* * *}$ & $50.000^{* * *}$ & $11.134^{* * *}$ & 2.661 \\
\hline & $\mathrm{X}_{110}$ & 5.338 & & $10.086^{* * *}$ & $5.823^{* *}$ & $19.484^{* * *}$ & $8.401^{* * *}$ & 0.089 \\
\hline & $\mathrm{X}_{111}$ & 5.286 & & $4.680^{* * *}$ & 0.743 & $35.419^{* * *}$ & $6.397^{* * *}$ & 1.336 \\
\hline & $\mathrm{X}_{112}$ & 5.367 & & $4.250^{* * *}$ & 0.031 & $35.419^{* * *}$ & $7.492^{* * *}$ & 1.372 \\
\hline \multirow{6}{*}{ 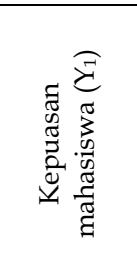 } & $Y_{11}$ & 5.624 & \multirow{6}{*}{5.585} & $2.976^{* *}$ & 1.252 & 0.567 & $5.379 * * *$ & 2.186 \\
\hline & $Y_{12}$ & 5.845 & & 1.925 & 0.011 & $3.027^{*}$ & $3.964^{* * *}$ & $4.023^{* *}$ \\
\hline & $Y_{13}$ & 5.664 & & $2.788^{* *}$ & 0.115 & 0.046 & $6.291^{* * *}$ & 2.607 \\
\hline & $\mathrm{Y}_{14}$ & 5.690 & & $2.518^{*}$ & 0.002 & 1.330 & $3.684^{* * *}$ & 2.161 \\
\hline & $Y_{15}$ & 5.317 & & $7.689^{* * *}$ & 1.404 & $14.635^{* * *}$ & $7.670^{* * *}$ & 0.110 \\
\hline & $Y_{16}$ & 5.372 & & $3.002^{* *}$ & 0.186 & 0.642 & $8.154^{* * *}$ & 0.200 \\
\hline \multirow{5}{*}{ 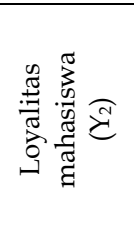 } & $\mathrm{Y}_{21}$ & 5.704 & \multirow{5}{*}{5.676} & $2.540^{*}$ & 0.009 & 1.478 & $6.145^{* * *}$ & $6.860^{* * *}$ \\
\hline & $Y_{22}$ & 5.593 & & $4.477^{* * *}$ & 0.356 & 2.221 & $4.322^{* * *}$ & $3.608^{*}$ \\
\hline & $\mathrm{Y}_{23}$ & 5.639 & & $5.432^{* * *}$ & 0.384 & 1.343 & $3.814^{* * *}$ & $4.738^{* *}$ \\
\hline & $Y_{24}$ & 5.610 & & $2.839 * *$ & 0.722 & 0.404 & $5.748^{* * *}$ & $11.363^{* * *}$ \\
\hline & $Y_{25}$ & 5.834 & & 1.761 & 0.077 & 0.213 & $2.855^{* * *}$ & 0.680 \\
\hline \multirow{5}{*}{ 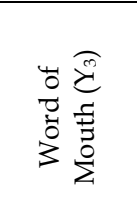 } & $Y_{31}$ & 5.779 & \multirow{5}{*}{5.811} & 1.515 & 0.731 & 2.246 & $3.241^{* * *}$ & $4.393^{* *}$ \\
\hline & $Y_{32}$ & 5.916 & & $2.549^{*}$ & 0.003 & 1.030 & $3.716^{* * *}$ & $7.618^{* * *}$ \\
\hline & $\mathrm{Y}_{33}$ & 5.782 & & $4.371^{* * *}$ & 0.065 & $4.836^{* *}$ & $3.247^{* * *}$ & $6.157^{* *}$ \\
\hline & $\mathrm{Y}_{34}$ & 5.665 & & $2.561^{*}$ & 0.178 & 0.943 & $6.176^{* * *}$ & $10.701^{* * *}$ \\
\hline & $Y_{35}$ & 5.915 & & $4.826^{* * *}$ & 0.556 & $3.764^{*}$ & $4.079 * * *$ & $10.987^{* * *}$ \\
\hline
\end{tabular}

*=P-value $<0.1,{ }^{* *}=P$-value $<0.05,{ }^{* * *}=P$-value $<0.01$

Sumber: data primer, diolah (2019)

Ini terjadi di semua indikator kualitas pelayanan. Sementara untuk rata-rata tanggapan tertinggi berada pada usia diatas 30 tahun $(5,82)$. Hal ini menunjukkan bahwa mahasiswa baru masih bisa menerima kondisi kualitas pelayanan yang ada karena batas toleransi mereka yang tinggi. Namun seiring dengan berjalannya waktu, mereka tidak bisa menerima kondisi yang sama. Mereka (usia 21-24) mengharapkan peningkatan kualitas pelayanan dibanding yang mereka peroleh sebelumnya. Mereka (usia 21-25) juga merasa kurang puas terhadap kampus (kepuasan mahasiswa).
Akibatnya loyalitas mereka terhadap kampus juga lebih rendah dibanding dengan kelompok usia lainnya. Kondisi ini membuat mereka lebih rendah minatnya dibanding dengan kelompok usia lainnya untuk mempromosikan kampus kepada pihak lain (word of mouth). Sebaliknya yang bisa menerima kondisi kualitas pelayanan saat ini adalah kelompok usia diatas 30 dan usia 25-30 mereka lebih bisa merasa puas terhadap kampus (kepuasan mahasiswa). Kondisi itu terjadi karena mereka lebih dewasa dan pada umumnya sudah bekerja sehingga bisa membandingkan pelayanan kampus dan 
layanan di lembaga atau organisasi lainnya. Namun dari sisi loyalitas, justru kelompok usia diatas 30 tahun dan usia 18-20 tahun yang mempunyai loyalitas yang lebih tinggi. Akibatnya dua kelompok inilah yang banyak membicarakan dan merekomendasi kan kampus keluar (word of mouth).

Dari sisi gender, ternyata tidak terlalu banyak perbedaan antara pria dan wanita. Perbedaan hanya terdapat pada kualitas pelayanan. Wanita lebih sensitif dibanding pria tentang keberadaan dan kehadiran dosen, ketersediaan dan kelayakan laboratorium kamputer dan perpustakaan yang memadai, serta adanya lembaga pelayanan. Namun untuk kepuasan mahasiswa, loyalitas mahasiswa maupun word of mouth tidak ada perbedaan tanggapan antara pria dan wanita.

Jika dilihat dari sisi tipe perguruan tinggi, terdapat beberapa perbedaan tanggapan. Untuk kualitas pelayanan, mahasiswa yang berasal dari perguruan tinggi pemerintah memberikan respon lebih rendah dibanding dengan mahasiswa yang berasal dari swasta. Tanggapan yang lebih rendah tersebut berasal dari dosen mengikuti praktek mengajar yang baik, staf administrasi sopan dan selalu bersedia membantu, database bagian administrasi sangat baik, ruangan kelas bersih dan nyaman, laboratorium komputer atau science tersedia dengan baik, pustaka memiliki buku yang memadai, perguruan tinggi menyediakan jasa konseling, lingkungan kampus nyaman untuk belajar yang baik, kampus memiliki keamanan yang baik. Hal ini terjadi karena perguruan tinggi swasta selalu berusaha menjaga kualitas pelayanannya, untuk bisa bersaing dengan perguruan tinggi negeri. Namun jika dilihat dari sisi kepuasan mahasiswa, secara umum tidak ada perbedaan antara mahasiswa dari perguruan tinggi pemerintah dengan swasta. Tanggapan mahasiswa dari perguruan tinggi pemerintah hanya lebih rendah dibanding mahasiswa dari perguruan tinggi swasta pada puas dengan kualitas pelayanan administrasi. Sebaliknya tanggapan mahasiswa yang berasal dari perguruan tinggi pemerintah justru lebih tinggi untuk puas dengan kualitas pelayanan akademik. Walaupun begitu, loyalitas mahasiswa untuk kedua kelompok mahasiswa ini tidak ada perbedaan yang berarti. Sebaliknya untuk word of mouth, tanggapan mahasiswa dari perguruan tinggi pemerintah lebih tinggi untuk saya akan merekomendasikan kepada orang lain untuk kuliah di sini dan saya bangga bisa berbagi pengalaman selama di kampus. Hal ini berarti faktor mahasiswa dari perguruan tinggi negeri lebih mau "menjual" perguruan tingginya dibanding dengan mahasiswa dari perguruan tinggi swasta.

Dilihat dari sisi program studi yang diikuti mahasiswa, ternyata semua indikator menunjukkan adanya perbedaan yang sangat signifikan. Untuk kualitas pelayanan terendah direspon oleh mahasiswa pada program studi keperawatan. Mereka menganggap semua hal lebih rendah dibanding dengan mahasiswa pada program studi lainnya. Sementara kualitas pelayanan yang dianggap paling baik direspon oleh mahasiswa yang mengambil program studi radiology. Namun untuk kepuasan mahasiswa, justru mahasiswa pada program studi teknik otomotif yang tingkat kepuasannya lebih rendah dibanding lainnya. Sementara untuk kepuasan yang lebih tinggi terdapat pada mahasiswa administrasi rumah sakit.

Tingginya kepuasan pada mahasiswa administrasi rumah sakit berimbas pada tingginya loyalitas mahasiswa mereka. Sementara loyalitas mahasiswa terendah dialami oleh mahasiswa keperawatan. Karena loyalitas mereka rendah, mengakibatkan mereka juga paling rendah minatnya untuk menginformasikan kampusnya pada orang lain (word of mouth). Mahasiswa yang paling gencar memberikan informasi kampus dilakukan oleh mahasiswa program studi administrasi rumah sakit.

Ada 18,90\% mahasiswa yang kuliah sambil bekerja. Pandangan mereka terhadap kualitas pelayanan kampus tidak jauh berbeda dibanding mahasiswa yang tidak bekerja. Pada laboratorium komputer atau science tersedia dengan baik, mereka justru 
lebih toleran dibanding dengan mahasiswa yang tidak bekerja. Pada sisi kepuasan mahasiswa juga tidak jauh berbeda. Walaupun mahasiswa yang bekerja merasa tidak terlalu puas dengan kualitas pelayanan akademik, namun secara umum mereka merasa puas. Jika dilihat dari loyalitas mahasiswa, mahasiswa yang bekerja memang kurang loyal dibanding dengan mahasiswa yang tidak bekerja.

Karena aktivitas mereka di kampus tidak banyak, maka tingkat loyalitas mereka cenderung lebih rendah. Akibatnya mahasiswa yang bekerja juga tidak banyak memberikan informasi kepada orang lain tentang kampus (word of mouth). Mahasiswa yang tidak bekerja lebih loyal terhadap perguruan tingginya karena sepanjang hari mereka lebih banyak menghabiskan waktu di kampus dengan kegiatan akademik dan ekstrakurikuler sehingga mereka lebih mencintai almamaternya.

\section{Testing The Hypothesis}

Berdasarkan pada proposed model yang sudah dibuat sebelumnya, telah diperoleh hasil pengujian hipotesis dengan menggunakan SEM pada Tabel 7 dan Gambar 2.

Table 7

Hasil Final SEM

\begin{tabular}{|c|c|c|c|c|c|c|}
\hline Hypothesis & $\begin{array}{c}\text { Exogenous } \\
\text { Variable }\end{array}$ & $\begin{array}{c}\text { Endogenous } \\
\text { Variable }\end{array}$ & $\begin{array}{c}\text { Standardized } \\
\text { Coefficient }\end{array}$ & $\begin{array}{c}\text { Critical } \\
\text { Ratio } \\
\end{array}$ & p-value & Conclusion \\
\hline$\overline{\mathrm{H}_{1}}$ & $\begin{array}{l}\text { Kualitas } \\
\text { pelayanan }\end{array}$ & $\begin{array}{l}\text { Kepuasan } \\
\text { mahasiswa }\end{array}$ & 0.600 & 18.403 & 0.000 & Significant \\
\hline $\mathbf{H}_{2}$ & $\begin{array}{l}\text { Kualitas } \\
\text { pelayanan }\end{array}$ & $\begin{array}{l}\text { Loyalitas } \\
\text { mahasiswa }\end{array}$ & 0.016 & 0.567 & 0.571 & Not significant \\
\hline $\mathbf{H}_{3}$ & $\begin{array}{l}\text { Kepuasan } \\
\text { mahasiswa }\end{array}$ & $\begin{array}{l}\text { Loyalitas } \\
\text { mahasiswa }\end{array}$ & 0.858 & 21.710 & 0.000 & Significant \\
\hline $\mathbf{H}_{4}$ & $\begin{array}{l}\text { Kepuasan } \\
\text { mahasiswa }\end{array}$ & Word of Mouth & 0.095 & 1.491 & 0.136 & Not significant \\
\hline $\mathbf{H}_{5}$ & $\begin{array}{l}\text { Loyalitas } \\
\text { mahasiswa }\end{array}$ & Word of Mouth & 0.677 & 10.425 & 0.000 & Significant \\
\hline
\end{tabular}

Sumber: data primer, diolah (2019)

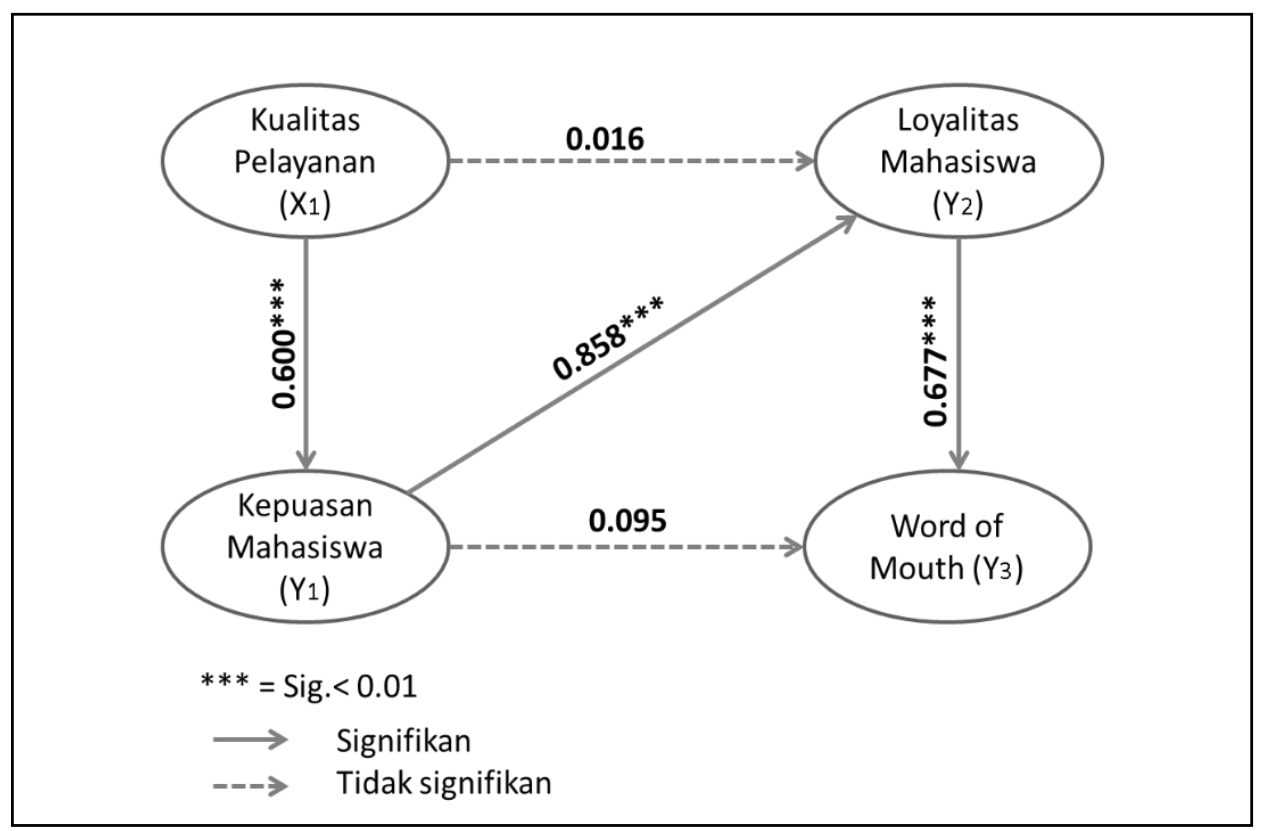

Gambar 2. Model Final 
Dari hasil analisis Gambar 2 dan tabel 7, terlihat bahwa hipotesis 1 yang menyatakan hubungan kualitas pelayanan dengan kepuasan mahasiswa, hipotesis 3 yang menyatakan hubungan kepuasan mahasiswa dengan loyalitas mahasiswa dan hipotesis 5 yang menyatakan hubungan loyalitas mahasiswa dengan word of mouth saja yang signifikan. Sedangkan hipotesis 2 yang menyatakan hubungan kualitas pelayanan dengan loyalitas mahasiswa dan hipotesis 4 yang menyatakan hubungan kepuasan mahasiswa dengan word of mouth ternyata hasilnya tidak signifikan.

Dari Gambar 2 juga diketahui bahwa kualitas pelayanan tidak berpengaruh signifikan terhadap loyalitas mahasiswa dan demikian pula halnya kepuasan mahasiswa tidak signifikan berpengaruh terhadap word of mouth. Tetapi lain halnya bila melalui kepuasan dan loyalitas, kualitas pelayanan berpengaruh siginifikan terhadap word of mouth bila melalui kepuasan dan loyalitas mahasiswa. Hal ini berarti, semakin baik kualitas pelayanan maka semakin puas mahasiswa, mahasiswa dan yang puas akan berpengaruh positif terhadap loyalitasnya dan mahasiswa yang loyalitasnya semakin meningkat akan cenderung melakukan promosi melalui word of mouth kepada keluarga dan rekannya yang lain.

\section{Pembahasan}

Hasil analisis memperlihatkan adanya hubungan positif antara kualitas pelayanan yang diberikan kepada mahasiswa dengan kepuasan mahasiswa. Hasil penelitian ini mendukung penelitian yang dilakukan oleh Alves dan Raposo, (2009); Annamdevula dan Bellamkonda, (2016b, 2016a); Chandra et al., (2019); Chandra et al., (2018); Duarte et al., (2012); Khoo et al. (2015). Sebaliknya hasil ini tidak mendukung hasil yang diperoleh (Dib dan Mokhles, 2013). Hasil ini menunjukkan kualitas pelayanan perlu mendapat perhatian yang serius dari institusi untuk bisa meraih kepuasan mahasiswa. Ini bisa dibuktikan dengan rendahnya kepuasan dari mahasiswa yang berusia 21-24 tahun akibat dari kualitas pelayanan yang rendah mereka dapatkan. Program studi yang perlu menjadi perhatian untuk perbaikan kualitas pelayanan adalah kebidanan, bisnis, kesehatan masyarakat dan teknik otomotif. Perbaikan yang perlu diperhatikan adalah mengenai database bagian administrasi sangat baik dan ruangan kelas bersih dan nyaman. Memang untuk kasus mahasiswa perguruan tinggi negeri, mereka akan tetap puas dengan kampus kendati kualitas pelayanan yang mereka dapatkan lebih rendah. Hal ini lebih disebabkan karena perguruan tinggi negeri merupakan kampus favorit. Kepuasan mereka akan berkurang jika pada masa yang akan datang muncul kampus favorit yang baru.

Kualitas pelayanan yang baik saja sebenarnya tidak akan menjamin mahasiswa akan menjadi loyal. Loyalitas mahasiswa akan muncul jika kualitas pelayanan yang baik juga ditunjang dengan kepuasan mahasiswa. Hasil ini mendukung hasil penelitian yang dilakukan oleh Annamdevula dan Bellamkonda, (2016b, 2016a); Chandra et al., (2019, 2018); Dib dan Mokhles, (2013); Duarte et al., (2012). Jadi mahasiswa yang merasa puas karena mendapat kualitas pelayanan yang baik yang akan menjadi loyal. Hal ini juga dibuktikan mahasiswa dengan usia 2124 tahun yang mendapat kualitas pelayanan lebih rendah menghasilkan kepuasan mahasiswa yang lebih rendah dan sekaligus membuat loyalitas mahasiswa juga lebih rendah. Begitu juga dengan program studi yang mendapat kualitas pelayanan yang lebih rendah juga menghasilkan kepuasan mahasiswa yang lebih rendah akibatnya loyalitas mahasiswa juga rendah. Sebaliknya jika dilihat dari tipe perguruan tinggi, ternyata kualitas pelayanan yang lebih rendah yang diperoleh mahasiswa, tidak membuat kepuasan mereka turun. Bahkan loyalitas mahasiswa mereka cenderung lebih tinggi dibanding dengan perguruan tinggi swasta.

Kepuasan mahasiswa yang tinggi tidak menjamin mahasiswa mau menyebarkan informasi positif kepada orang lain (word of 
mouth). Mahasiswa yang merasa puas dengan kampus ditunjang dengan loyalitas mahasiswa yang tinggi baru bisa mendorong mahasiswa untuk menyebarkan informasi positif tentang kampus kepada orang lain (word of mouth). Penelitian ini tidak mendukung penelitian yang dilakukan oleh Mansori et al., (2014); Ranaweera dan Prabhu, (2003) yang menemukan adanya hubungan positif antara kepuasan mahasiswa dengan word of mouth. Hasil penelitian ini justru mendukung penelitian yang dilakukan oleh Alves dan Raposo, (2007) yang menemukan tidak adanya hubungan yang signifikan antara kepuasan mahasiswa dengan word of mouth, tetapi terdapat hubungan yang sangat kuat antara loyalitas mahasiswa dengan word of mouth. Hal ini tergambar pada hasil mahasiswa yang berusia 21-24 tahun memberikan respon lebih rendah untuk kepuasan mahasiswa, juga mempunyai loyalitas mahasiswa lebih rendah dan mereka juga lebih rendah mau memberikan informasi positif tentang kampus kepada pihak lain (word of mouth). Begitu juga program studi yang mendapat respon rendah untuk kepuasan mahasiswa seperti keperawatan dan teknik otomotif juga mendapat loyalitas mahasiswa yang relatif lebih rendah dan akhirnya respon word of mouth juga rendah.

Kualitas pelayanan merupakan hal yang krusial untuk segera diperbaiki oleh perguruan tinggi yang ada di Riau. Untuk bisa menghadapi persaingan dengan perguruan tinggi lain termasuk dari luar negeri, kualitas pelayanan perlu diperbaiki. Dengan akan masuknya perguruan tinggi asing, maka kualitas pelayanan yang tidak ditingkatkan akan berimplikasi pada menurunnya jumlah mahasiswa dimasa yang akan datang. Kualitas pelayanan yang baik akan meningkatkan kepuasan mahasiswa dan berikutnya akan meningkatkan loyalitas mahasiswa dan akhirnya mereka akan memberikan informasi yang positif kepada calon mahasiswa. Mahasiswa cenderung memilih perguruan tinggi yang memberikan kualitas pelayanan dan kepuasan mahasiswa yang tinggi (Tahir et al., 2010). Karena kualitas pelayanan yang baik akan menentukan jumlah mahasiswa yang mendaftar (Chen, 2016). Hal ini sangat penting untuk menjaga keberlangsungan perguruan tinggi di propinsi Riau.

\section{SIMPULAN DAN SARAN Simpulan}

Dari hasil pengujian hipotesis dan pembahasan dapat disimpulkan bahwa hubungan kualitas pelayanan dengan kepuasan mahasiswa, hubungan kepuasan mahasiswa dengan loyalitas mahasiswa dan hubungan loyalitas mahasiswa dengan word of mouth berpengaruh signifikan. Sedangkan hubungan kualitas pelayanan dengan loyalitas mahasiswa dan hubungan kepuasan mahasiswa dengan word of mouth hasilnya tidak signifikan. Tetapi lain halnya bila melalui kepuasan dan loyalitas, kualitas pelayanan berpengaruh siginifikan terhadap word of mouth bila melalui kepuasan dan loyalitas mahasiswa.

\section{Saran}

Kualitas pelayanan yang baik saja tidak menjamin mahasiswa akan menjadi loyal, untuk itu perlu dipastikan bahwa pelayanan yang diberikan dapat memuaskan mahasiswa. Mahasiswa yang puas akan meningkat loyalitasnya sehingga diharapkan dapat membantu perguruan tinggi untuk mempromosikan perguruan tingginya melalui word of mouth.

Kualitas pelayanan merupakan hal yang penting untuk segera diperbaiki oleh perguruan tinggi yang ada di Riau. Terutama untuk menghadapi persaingan dengan perguruan tinggi lain termasuk dari luar negeri. Kebijakan pemerintah yang memberi peluang bagi perguruan tinggi asing untuk masuk ke Indonesia perlu disikapi dengan meningkatkan kualitas pelayanan secara konsisten. Riau merupakan provinsi yang bertetangga langsung dengan negara Malaysia dan Singapura. Kualitas dan pelayanan di perguruan tinggi dua negara ini diketahui lebih baik dari beberapa perguruan tinggi yang ada di Riau. Perguruan tinggi di Riau 
perlu secara aktif meningkatkan kualitas pelayanan untuk mensiasati kondisi ini. Dengan akan masuknya perguruan tinggi asing, maka kualitas pelayanan yang tidak ditingkatkan dapat berimplikasi pada menurunnya jumlah mahasiswa dimasa yang akan datang. Kualitas pelayanan yang baik akan meningkatkan kepuasan mahasiswa dan berikutnya akan meningkatkan loyalitas mahasiswa dan akhirnya mereka akan memberikan kesan informasi positif kepada calon mahasiswa.

Kepuasan mahasiswa yang tinggi tidak menjamin mahasiswa mau menyebarkan informasi positif kepada orang lain (word of mouth). Mahasiswa yang merasa puas dengan kampus ditunjang dengan loyalitas mahasiswa yang tinggi baru bisa mendorong mahasiswa untuk menyebarkan informasi positif tentang kampus kepada orang lain (word of mouth).

Mengingat karakteristik responden untuk perguruan tinggi negeri dan swasta berbeda, maka ada baiknya untuk diteliti kembali khusus untuk perguruan tinggi swasta dan negeri secara terpisah. Diharapkan juga pada peneliti berikutnya untuk menambah variabel lain seperti image pada penelitiannya.

\section{DAFTAR PUSTAKA}

Abdullah, F. 2006. Measuring service quality in higher education: HEdPERF versus SERVPERF. Marketing Intelligence $\mathcal{E}$ Planning 24(1): 31-47. https://doi.org/ 10.1108/02634500610641543

Afridi, S. A., A. Khattak, dan A. Khan. 2016. Measurement of Service Quality Gap in The Selected Private Universities/ Institutes of Peshawar Using SERVQUAL Model. City University Research Journal 06(01): 61-69. Retrieved from http://www.cityuniversity.edu.pk/cur j/Journals/Journal/Jan 2016/artcile 05a.pdf

Alves, H. dan M. Raposo, M. 2007. Conceptual model of student satisfaction in higher education. Total Quality Mana- gement and Business Excellence 18(5): 571588. https://doi.org/10.1080 $=14783360$ 601074315

Alves, H. dan M. Raposo. 2009. The measurement of the construct satisfaction in higher education. Service Industries Journal 29(2): 203-218. https://doi.org/ $10.1080 / 02642060802294995$

Anderson, E. W., C. Fornell, dan D. R. Lehmann. 1994. Customer Satisfaction, Market Share, and Profitability: Findings from Sweden. Journal of Marketing 58(3): 53-66. https://doi.org/10.2307/ 1252310

Annamdevula, S. dan R. S. Bellamkonda. 2016a. Effect of Student Perceived Service Quality on Student Satisfaction, Loyalty and Motivation in Indian University. Journal of Service Management 11(2): 488-517.

https:/ / doi.org/10.1108/MBE-09-20160047

Annamdevula, S. dan R. S. Bellamkonda. 2016b. The effects of service quality on student loyalty: the mediating role of student satisfaction. Journal of Service Management 11(2): 446-462. https://doi.org/DOI 10.1108/JM2-042014-0031

Arambewela, R. dan J. Hall. 2006. A Comparative Analysis of International Education Satisfaction Using SERVQUAL. Journal of Services Research 6: 141-163.

Retrieved from http:/ / search.ebscohost. com/login.aspx?direct $=$ true $\& d b=b u h \&$ AN $=22535699 \&$ site $=$ ehost - live

Bolton, R. N., K. N. Lemon, dan P. C. Verhoef. 2004. The Theoretical Underpinnings of Customer Asset Management: A Framework and Propositions for Future Research. Journal of the Academy of Marketing Science 32(3): 271292.

https://doi.org/DOh10.1177/00920703 04263341

Calvo-Porral, C., J.-P. Lévy-Mangin, dan I. Novo-Corti. 2013. Perceived quality in higher education: an empirical study. Marketing Intelligence \& Planning 31(6): 
601-619. https://doi.org/10.1108/MIP11-2012-0136

Chandra, T., L. Hafni, S. Chandra, A. A. Purwati, dan J. Chandra. 2019. The influence of service quality, university image on student satisfaction and student loyalty. Benchmarking: An International Journal 26(6).

https://doi.org/10.1108/BIJ-07-20180212

Chandra, T., M. Ng, S. Chandra, dan Priyono. 2018. The Effect of Service Quality on Student Satisfaction and Student Loyalty: An Empirical Study. Journal of Social Studies Education Research 9(3): 109-131.

Retrieved from http://jsser.org/article /view/5000215807

Chen, Y. 2016. An Empirical Study on the Student Experience of Higher Education Service Quality in Taiwan. International Journal of Management Sciences 6(12): 582-594.

Cronin, J. J., dan S. A. Taylor. 1992. Measuring Service Quality: A Reexamination and Extension. Journal of Marketing 56(3): 55.

https://doi.org/10.2307/1252296

de Jager, J. dan G. Gbadamosi. 2010. Specific remedy for specific problem: Measuring service quality in South African higher education. Higher Education 60(3): 251267.

https://doi.org/10.1007/s10734-0099298-6

Dib, H. dan A. Mokhles. 2013. The Impact of Service Quality on Student Satisfaction and Behavioral Consequences in Higher Education Services. International Journal of Economy, Management and Social Sciences 2(6): 285-290.

https://doi.org/10.5296/jmr.v2i2.418

Duarte, P. O., M. B. Raposo, dan H. B. Alves. 2012. Using a Satisfaction Index to Compare Students' Satisfaction During and After Higher Education Service Consumption. Tertiary Education and Management 18(1): 17-40. https://doi. org/10.1080/13583883.2011.609564
Duffy, D. L. 2003. Internal and external factors which affect customer loyalty. Journal of Consumer Marketing 20(5): 480485.

https://doi.org/10.1108/073637603104 89715

Gruber, T., S. FuB, dan M. G. Zikuda. 2010. Examining Student Satisfaction with Higher Education Services Using a New Measurement Tool. International Journal of Public Sector Management 23(2): 105123.

Retrieved from http://www.emeraldin sight.com/doi/abs/10.1108/095135510 11022474

Hair, J. F. J., R. E. Anderson, R. L. Tatham, dan W. C. Black. 1998. Multivariate Data Analysis (Fifth edit). Prentice Hall International, inc.

Henning-Thurau, T., M. F. Langer, dan U. Hansen. 2001. Modeling and Managing Student Loyalty - An Approach Based on the Concept of Relationship Quality. Journal of Service Research 3(4): 331-344. https://doi.org/doi=10.1.1.456.6663

Heung, V. C., C. Mok, dan A. Kwan. 1996. Brand Loyalty in Hotels: an Exploratory Study of Overseas Visitor to Hong Kong. Australian Journal of Hospitality Management 3(1): 1-11.

Kanakana, M. G. 2014. Assessing Service Quality in Higher Education using the SERVQUAL Tool. International Conference on Industrial Engineering and Operations Management 1(969): 68-74.

Retrieved from http://iieom.org/ieom 2014/pdfs/24.pdf

Khoo, S., H. Ha, dan S. L. T. McGregor. 2015. Service quality and student/ customer satisfaction in the private tertiary education sector in Singapore. Journal of Service Management 26(2): 430-444. https://doi.org/10.1108/MBE-09-20160047

Kitapci, O. dan D. Taylan. 2009. The differences in customer complaint behaviour between loyal customers and first comers in the retail banking industry: The case of Turkish customers. 
Management Research News 32(10): 932941.

https://doi.org/DOI10.1108/014091709 10994141

Lagrosen, S., R. Seyyed-Hashemi, dan M. Leitner. 2004. Examination of the dimensions of quality in higher education. Quality Assurance in Education 12(2): 61-69.

https://doi.org/10.1108/096848804105 36431

Mahapatra, S. S. dan M. S. Khan. 2007. A framework for analysing quality in education settings. European Journal of Engineering Education 32(2): 205-217. https://doi.org/10.1080/030437906011 18606

Mansori, S., A. Vaz, dan Z. M. M. Ismail. 2014. Service quality, satisfaction and student loyalty in Malaysian private education. Asian Social Science 10(7): 5766.

https://doi.org/10.5539/ass.v10n7p57

Marzo Navarro, M., M. Pedraja Iglesias, dan P. Rivera Torres. 2005. A new management element for universities: satis faction with the offered courses. International Journal of Educational Management 19(6): 505-526.

https://doi.org/10.1108/095135405106 17454

Ngo, M. V. dan H. H. Nguyen. 2016. The Relationship between Service Quality, Customer Satisfaction and Customer Loyalty: An Investigation in Vietnamese Retail Banking Sector. Journal of Competitiveness 8(2): 103-116. https://doi.org/10.7441/joc.2016.02.08

Oliver, R. L. 1989. Processing of the Satisfaction Response in Consumption: a Suggested Framework and Research Propositions. Journal of Consumer Satisfaction, Dissatisfaction $\mathcal{E}$ Complaining Behavior 2: 1-16. https://doi.org/10.1086/209358

Olorunniwo, F., M. K. Hsu, dan G. J. Udo. 2006. Service quality, customer satisfaction, and behavioral intentions in the service factory. Journal of Services
Marketing 20(1): 59-72.

https://doi.org/10.1108/088760406106 46581

Parasuraman, A., V. A. Zeithaml, dan L. L. Berry. 1985. A conceptual model of service quality and its implications for future research. The Journal of Marketing, 49(4): 41-50.

https://doi.org/10.2307/1251430

Parasuraman, A., V. A. Zeithaml, dan L. L. Berry. 1988. SERQUAL: A Multiple-Item scale for Measuring Consumer Perceptions of Service Quality. Journal of Retailing 64(1): 12-40.

https://doi.org/10.1016/S0148-2963 (99)00084-3

Ranaweera, C. dan J. Prabhu. 2003. On the relative importance of customer satisfaction and trust as determinants of customer retention and positive word of mouth. Journal of Targeting, Measurement and Analysis for Marketing 12(1): 82-90. https://doi.org/10.1057/palgrave.jt.57 40100

Sekaran, U. 2003. Reseach Methods For Business, A Skill Building Approach (Fourth Edi). John Wiley \& Son, Inc.

Senthilkumar, N. dan A. Arulraj. 2011. SQMHEI - determination of service quality measurement of higher education in India. Journal of Modelling in Management 6(1): 60-78.

https://doi.org/10.1108/174656611111 12502

Seth, N., S. G. Deshmukh, dan P. Vrat. 2005. Service quality models: a review. International Journal of Quality $\mathcal{E}$ Reliability Management 22(9): 913-949.

https:/ / doi.org/10.1108/026567105106 25211

Stevens, P., B. Knutson, dan M. Patton. 1995. Dineserv: a tool for measuring serqual restaurants. Cornell Hotel and Restaurant Administration Quarterly 36(2): 56-60. https://doi.org/https://doi.org/10.10 16/0010-8804(95)93844-K

Sultan, P. dan H. Yin Wong. 2010. Service quality in higher education - a review and research agenda. International 
Journal of Quality and Service Sciences 2(2): 259-272.

https://doi.org/10.1108/175666910110 57393

Tahir, I. M., N. M. A. Bakar, dan W. Z. W. Ismail. 2010. Importance-Performance Analysis of Service Quality among Business Students: An Exploratory Study. Interdiciplinary Journal of Contempory Research of Business 2(1): 330-341. Retrieved from https://www.research gate.net/publication/202009720_Impor tance_Performance_Analysis_of_Servic e_Quality_among_Business_Students_ An_Exploratory_Study

Tse, D. K. dan P. C. Wilton. 1998. Models of customer satisfaction formation: an extension. Journal of Marketing Research
25(2): 204-212.

Vaz, A. dan S. Mansori. 2013. Malaysian private education quality: Application of SERVQUAL model. International Education Studies 6(4): 164-170. https://doi.org/10.5539/ies.v6n4p164

Yousapronpaiboon, K. 2014. SERVQUAL: Measuring Higher Education Service Quality in Thailand. Procedia - Social and Behavioral Sciences 116: 1088-1095. https://doi.org/10.1016/j.sbspro.2014. 01.350

Zeithaml, V. A., L. L. Berry, dan A. Parasuraman. 1996. The Behavioral Consequences of Service Quality. Journal of Marketing 60(2): 31 .

https:/ / doi.org/10.2307/1251929 